\title{
Molecular alterations in the TCR signaling pathway in patients with aplastic anemia
}

Bo Li ${ }^{i^{*}}$, Lixing Guo ${ }^{1+}$, Yuping Zhang ${ }^{2}$, Yankai Xiao ${ }^{3}$, Mingjuan Wu ${ }^{1,3}$, Lingling Zhou ${ }^{3}$, Shaohua Chen ${ }^{1}$, Lijian Yang ${ }^{1}$, Xiang $\mathrm{Lu}^{4}$ and Yangqiu Li $\mathrm{i}^{1,3,5^{*}}$

\begin{abstract}
Background: A previous study has demonstrated a significantly increased $\operatorname{CD} 3 \zeta$ gene expression level in aplastic anemia (AA). However, the mechanism underlying the upregulated CD3 $\zeta$ mRNA expression level and that of T cell activation signaling molecules in AA patients remains unclear. Thus, we investigated the expression levels of the

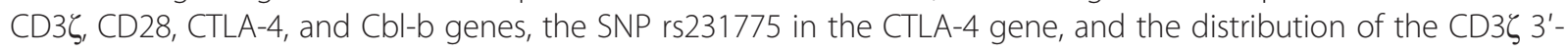
UTR splice variant in AA patients.
\end{abstract}

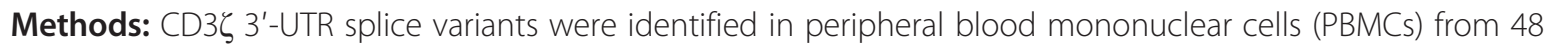
healthy individuals and 67 patients with AA [37 cases of severe aplastic anemia (SAA) and 30 cases of non-sever aplastic anemia (NSAA)] by RT-PCR. CD3ל, CD28, CTLA-4, and Cbl-b gene expression was analyzed by real-time quantitative PCR. The SNP rs231775 in CTLA-4 gene was analyzed by PCR-RFLP.

Results: $C D 3 \zeta$ and CD28 expression was significantly higher, while CTLA-4 and Cbl-b expression was significantly

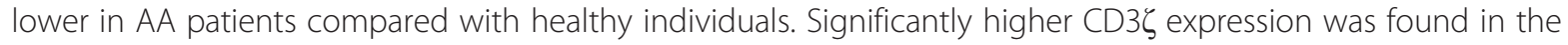
NSAA subgroup compared with the SAA subgroup. $64 \%$ of the AA samples had the same genotype $\left(\mathrm{WT}^{+} \mathrm{AS} \mathrm{S}^{+} \mathrm{CD} 3 \zeta\right.$ $3^{\prime}-$ UTR); $22 \%$ of the AA patients had a $\mathrm{WT}^{+} A S^{-} \mathrm{CD} 3 \zeta 3^{\prime}-$ UTR genotype, and $14 \%$ of the AA patients had a WT- AS ${ }^{+} \mathrm{CD} 3 \zeta 3^{\prime}-\mathrm{UTR}$ genotype. The $\mathrm{CD} 3 \zeta$ expression level of $\mathrm{WT}^{-} \mathrm{AS}^{+}$subgroup was the highest in the SAA patients. A significantly higher frequency of the GG genotype (mutant type, homozygous) of SNP rs231775 in CTLA-4 gene was found in the AA patients. Positive correlation between the CTLA-4 and Cbl-b gene expression levels was found in healthy individuals with the AA and AG genotypes, but not in the AA patients.

Conclusions: This is the first study analyzing the expression characteristics of the CD28, CTLA-4, and Cbl-b genes in AA. Our results suggest that aberrant $T$ cell activation may be related to the first and second signals of $T$ cell activation in AA. The GG genotype of SNP rs231775 in CTLA-4 gene might be associated with AA risk in the

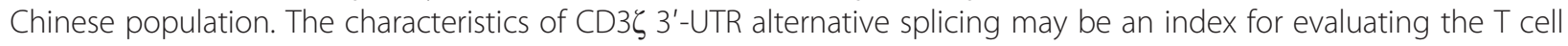
activation status in AA patients, particularly in SAA patients.

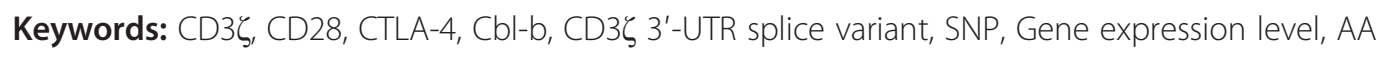

\footnotetext{
* Correspondence: libo517@jnu.edu.cn; yangqiuli@hotmail.com

${ }^{\dagger}$ Equal contributors

${ }^{1}$ Institute of Hematology, Medical College, Jinan University, Guangzhou,

China

Full list of author information is available at the end of the article
} 


\section{Background}

Aplastic anemia (AA) is a serious hematological disorder characterized by pancytopenia [1-3]. AA is an immunemediated destruction of hematopoietic cells caused by abnormally activated $\mathrm{T}$ cells for most cases $[4,5]$. Our previous study has shown that, in addition to abnormal distribution and clonal expansion of the $\mathrm{T}$ cell receptor (TCR) repertoire, there is significantly higher $\mathrm{CD} 3 \zeta$ expression in T cells in AA patients [6]. An abnormal CD3ל gene expression level may directly represent a characteristic of abnormal $\mathrm{T}$ cell activation.

$\mathrm{T}$ cell recognition of antigenic peptide/major histocompatibility complexes plays a pivotal role in the initiation and regulation of the adaptive immune response [7-9]. TCR activation plays a crucial role in $\mathrm{T}$ cell function. The TCR itself does not possess signaling domains. Instead, the TCR is non-covalently coupled to a conserved multisubunit signaling apparatus, i.e., the CD3 complex, which comprises the $\mathrm{CD} 3 \varepsilon \gamma, \mathrm{CD} 3 \varepsilon \delta$, and $\mathrm{CD} 3 \zeta \zeta$ dimmers [10]. However, the TCR/CD3 signaling complex alone is insufficient for antigen-specific $\mathrm{T}$ cell responses and a second pathway, co-stimulatory signaling, is required for $\mathrm{T}$ cell immune responses. The co-stimulatory signaling molecule CD28 that is found on T cells must bind B7-1 and B7-2, which are expressed on antigen presenting cells (APCs), to trigger $\mathrm{T}$ cell activation $[11,12]$. Upon T cell activation, cytotoxic T-lymphocyte antigen-4 (CTLA-4) is induced and outcompetes CD28 for B7-1 and B7-2 ligands, thereby preventing excessive $\mathrm{T}$ cell expansion [13, 14]. This mechanism provides a key checkpoint in the regulation of $\mathrm{T}$ cell immunity $[15,16]$. The SNP rs231775, A > G transition mutation which is located at exon 1 in the CTLA-4 gene, has been reported to potentially influence the inhibitory function of CTLA-4 by reducing its cell surface expression $[17,18]$.

Optimal $\mathrm{T}$ cell activation requires signaling through the TCR and the CD28 co-stimulatory receptor. CD28 costimulation is believed to set the threshold for T cell activation. Casitas B-lineage lymphoma proto-oncogene-b (Cbl-b), a RING finger E3 ubiquitin-protein ligase, is involved in CD28-dependent $T$ cell activation [19]. Results from $\mathrm{T}$ cell activation assays in vitro have shown that CD28 co-stimulation promotes TCR-induced Cbl-b degradation, whereas CTLA-4-B7 interaction potentiates TCR-induced Cbl-b re-expression [20].

Expression of the $\mathrm{CD} 3 \zeta$ gene is regulated at the transcriptional, posttranscriptional, and posttranslational levels [21]. As previously described, there are two isoforms of the CD3 3 3'-UTR: a wild type (WT) isoform (906 bp) and an alternatively spliced (AS) isoform (344 bp). Abnormal CD3 $\zeta$ expression was found in $\mathrm{T}$ cell from SLE patients, and this may be associated with decreased stability and translation of $\mathrm{CD} 3 \zeta$ mRNAs that contain AS $\mathrm{CD} 3 \zeta$ 3 '-UTRs [22]. However, the mechanism of upregulating the $\mathrm{CD} 3 \zeta$ mRNA expression level in AA patients is unclear.

Thus, we investigated the expression level of the CD28, CTLA-4, Cbl-b, and CD3 $\zeta$ genes, the SNP rs231775 in CTLA-4 gene, CD3 $\zeta$-regulating factors, and the distribution of the CD3 3 ' -UTR splice variant. We concluded that analysis of these factors may facilitate the comprehensive understanding of the abnormal $\mathrm{T}$ cell immune characteristics of AA.

\section{Results}

The expression levels of CD3 $\zeta$, CD28, CTLA-4, and Cbl-b in AA The expression levels of the CD3ל, CD28, CTLA-4, and Cbl-b genes in cDNA from PBMCs from 67 AA patients before treatment and 48 healthy individuals were quantitatively assessed by real-time polymerase chain reaction (PCR) using the SYBR Green I technique. The results demonstrated an increased expression level for CD28 (median 0.75) and $\mathrm{CD} 3 \zeta$ (median 1.27) in AA patients compared with healthy individuals (CD28 0.49, $P<0.01$;

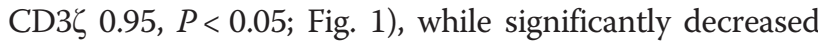
CTLA-4 (median 0.13) and Cbl-b (median 0.27) expression was found (CTLA-4 0.18, P<0.01; Cbl-b 0.55, $P<$ 0.01; Fig. 1). Significantly increased CD3ל expression (median: 0.13) was found in the non-severe aplastic anemia patients (NSAA) compared with sever aplastic anemia patients (SAA, median: $0.18, P<0.05$ ). There were no significant differences in CD28, CTLA-4, and Cbl-b expression between the SAA and NSAA groups (Fig. 2).

\section{The expression characteristics of the $\mathrm{CD} 3 \zeta$ gene with different $\mathrm{CD} 3 \zeta$ 3'-UTR isoforms in AA}

Two types of CD3 3 3'-UTR splicing variants, WT and AS CD3 3 3'-UTR, were detected in all of the healthy individuals. However, a significantly lower frequency of the $\mathrm{WT}^{+} \mathrm{AS}^{+} \mathrm{CD} 3 \zeta 3^{\prime}$-UTR genotype was detected in the AA patients (43 cases, $P<0.01$ ), and a significantly higher frequency of the $\mathrm{WT}^{+} \mathrm{AS} \mathrm{CD}^{-} \zeta 3^{\prime}$-UTR (15 cases, $P<0.01$ ) and $\mathrm{WT}^{-} \mathrm{AS}^{+} \mathrm{CD} 3 \zeta 3^{\prime}-\mathrm{UTR}$ (9 cases, $P<0.01$ ) genotypes were detected in the AA patients (Fig. 3a). There were no significant differences in the frequencies of the three types of CD3 $\zeta 3$ '-UTR between the SAA and NSAA patients although the frequency of the WTAS ${ }^{+}$CD3 $\zeta 3$ '-UTR was high in the SAA patients (19\%) compared with that of the NSAA patients $(7 \%)$, while the $\mathrm{WT}^{+} \mathrm{AS}^{+} \mathrm{CD} 3 \zeta 3^{\prime}$-UTR frequency was low in the SAA patients $(57 \%)$ compared with that of the NSAA patients (73\%).

Based on the CD3 $\zeta 3^{\prime}$-UTR isoform expression, we divided the 67 AA cases into three subgroups: $\mathrm{WT}^{+} \mathrm{AS}^{+}$, $\mathrm{WT}^{+} \mathrm{AS}^{-}$and $\mathrm{WT}^{-} \mathrm{AS}^{+}$. There were no significant differences in the $\mathrm{CD} 3 \zeta$ expression among the three subgroups. To better comprehend the difference in the $\mathrm{CD} 3 \zeta$ expression level between the SAA and NSAA 

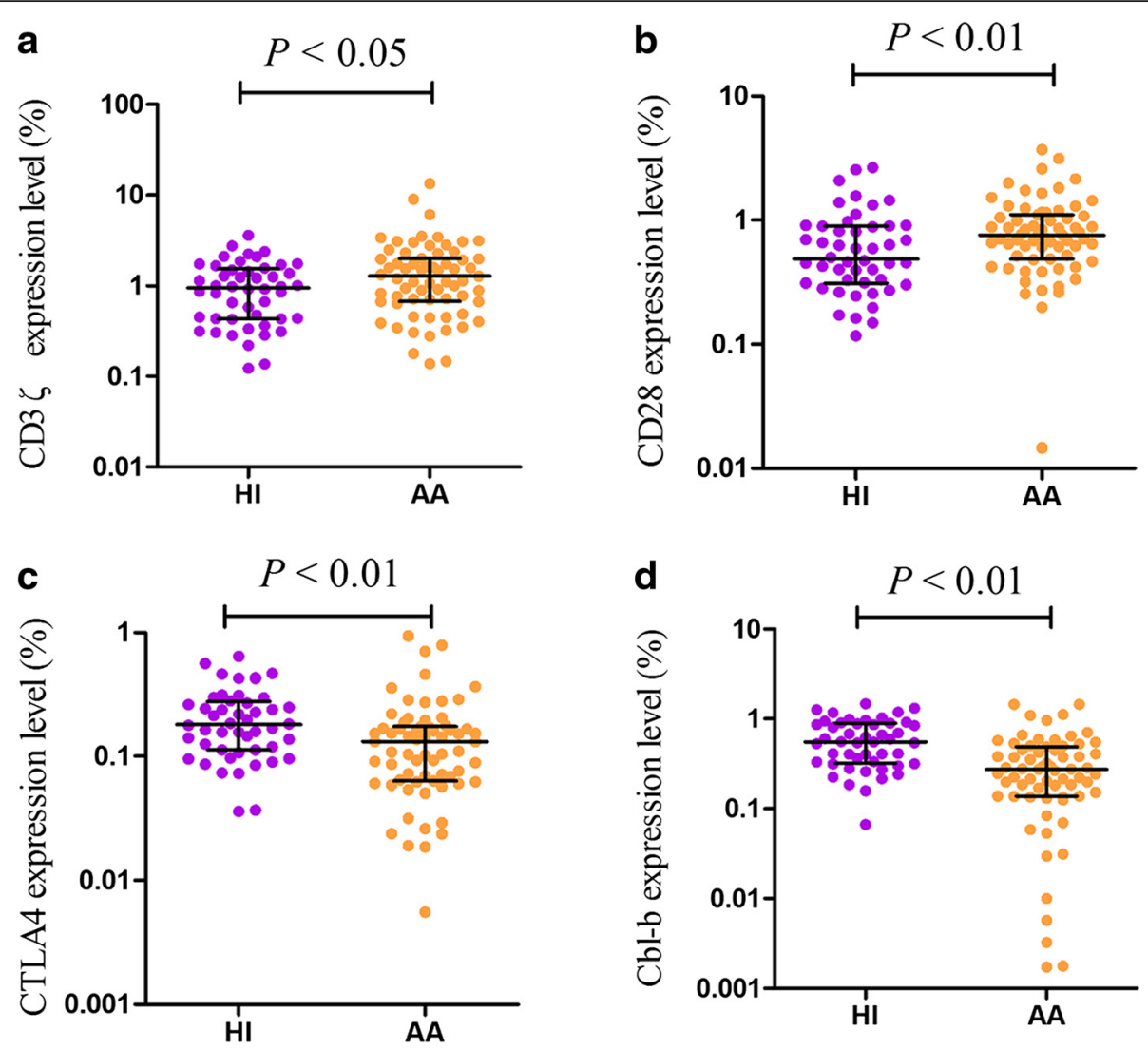

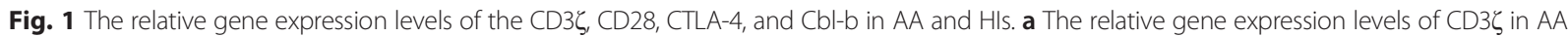
and $H \mathrm{H} s ; \mathbf{b}$ the relative gene expression levels of $\mathrm{CD} 28$ in AA and $H \mathrm{Hs} ; \mathbf{c}$ the relative gene expression levels of CTLA-4 in AA and HIs; $\mathbf{d}$ the relative gene expression levels of $\mathrm{Cl}-\mathrm{b}$ in $\mathrm{AA}$ and $\mathrm{HIs}$

patients, we compared the $\mathrm{CD} 3 \zeta$ expression level in the $\mathrm{WT}^{+} \mathrm{AS}^{+}, \mathrm{WT}^{+} \mathrm{AS}^{-}$, and $\mathrm{WT}^{-} \mathrm{AS}^{+}$subgroups in the SAA and NSAA patients. A significantly increased CD3 $\zeta$ expression level (median 1.46) was found in the $\mathrm{WT}^{-} \mathrm{AS}^{+}$ subgroup compared with the $\mathrm{WT}^{+} \mathrm{AS}^{+}$(median 0.78, $P$ $<0.05$ ) and $\mathrm{WT}^{+} \mathrm{AS}^{-}$subgroups (median $0.45, P=0.06$ ) in the SAA patients. However, there were no significant differences in the $\mathrm{CD} 3 \zeta$ expression level among the three subgroups in the NSAA patients (Fig. 3b).

\section{The genotype frequency for SNP rs231775 in CTLA-4 gene in $A A$}

The genotype distribution for SNP rs231775 in CTLA-4 gene in the AA patients (67 cases) and healthy individuals (84 cases) is shown in Fig. 4a, b. Gel electrophoresis results from TseI digests and the sequences of the different genotypes of SNP rs231775 in CTLA-4 gene are shown in Fig. 4c-f. AA patients had a borderline significantly higher frequency of the GG homozygous genotype compared with healthy individuals (46 \% vs. $31 \%$, OR = 1.92, $95 \% \mathrm{CI}=0.99-3.74, P=0.05)$. AA patients had a significantly higher frequency of the $G$ allele of SNP rs231775 in CTLA-4 gene compared with healthy individuals $(60 \%$ vs. $48 \%, \mathrm{OR}=0.61 ; 95 \% \mathrm{CI}=0.39$ $0.97, P=0.03)$. Analysis of the AA patients with the different genotypes for correlations with clinical parameters including age of onset, gender, severity of AA, and laboratory parameters was performed. However, no clinical or laboratory parameters were found to have a significant association with different genotypes of SNP rs231775 in CTLA-4 gene. In addition, the CTLA-4 expression level in the AA patients and healthy individuals had no significant association with the genotypes of SNP rs231775 in CTLA-4 gene.

\section{Correlation of the relative expression of CTLA-4 and Cbl-b in AA}

It has been reported that CTLA-4 regulates Cbl-b at the transcriptional level. We next estimated the correlation between the CTLA-4 and Cbl-b gene expression levels in AA patients and healthy individuals. There was a significant correlation between the expression levels of the CTLA-4 and Cbl-b genes in healthy individuals with the AA $(\mathrm{rs}=0.59, P=0.02)$ and AG $(\mathrm{rs}=0.58, P=0.03)$ genotypes, while there was no significant correlation between the expression levels of the CTLA-4 and Cbl-b 

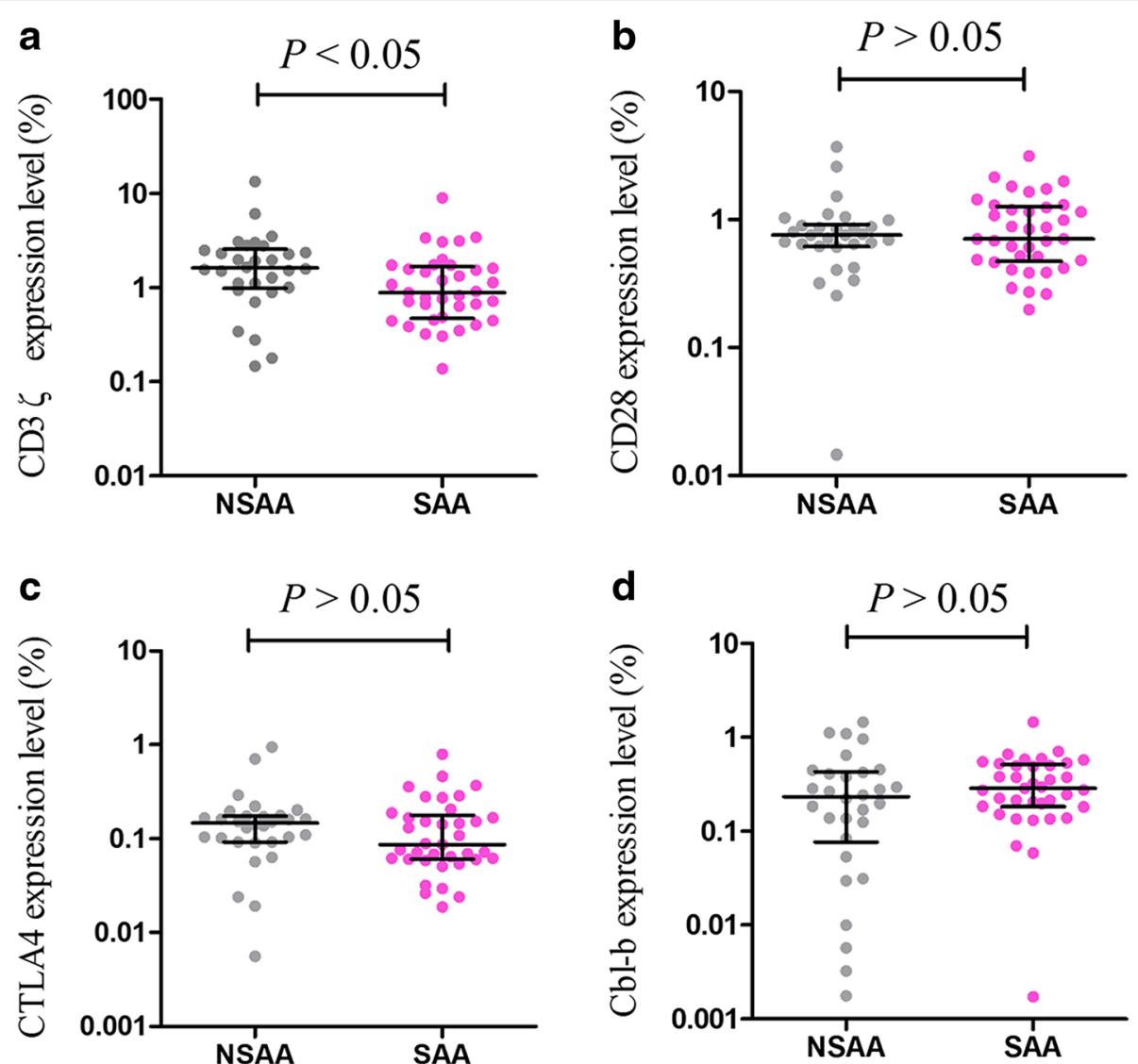

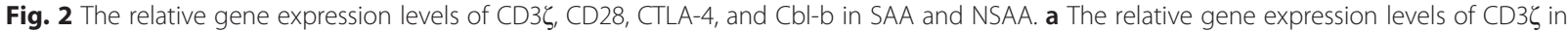
SAA and NSAA; $\boldsymbol{b}$ the relative gene expression levels of CD28 in SAA and NSAA; $\boldsymbol{c}$ the relative gene expression levels of CTLA-4 in SAA and NSAA; d the relative gene expression levels of Cbl-b in SAA and NSAA

genes ( $\mathrm{rs}=-0.09, P=0.71)$ in healthy individuals with the GG genotype (Fig. 5). In all of the patients with the various genotypes, there was no significant correlation between the expression levels of the CTLA-4 and Cbl-b genes.

\section{Discussion}

AA is an immune-mediated disease in which $\mathrm{T}$ cell target hematopoietic cells $[23,24]$. The precise mechanism of $\mathrm{T}$ cell activation in AA pathogenesis remains unknown. TCR signaling plays an important role in $\mathrm{T}$ cell
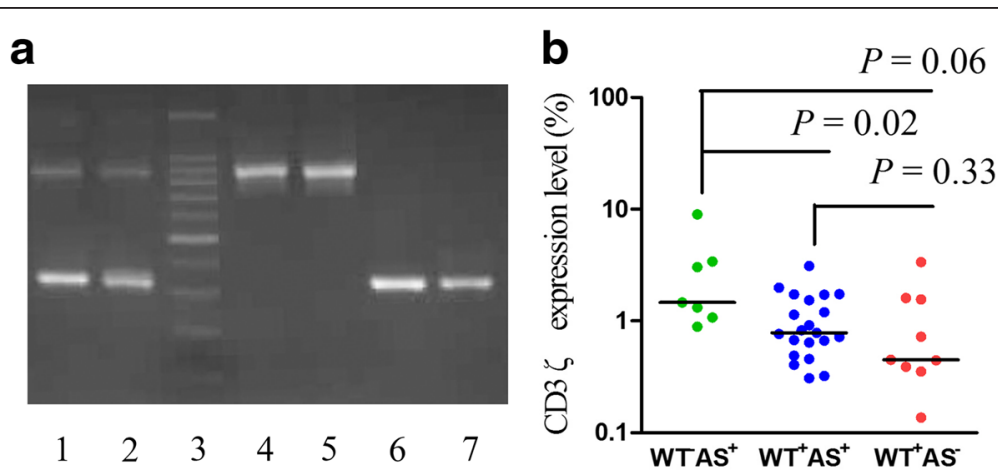

Fig. 3 CD3 $\zeta 3^{\prime}$-UTR splicing variant isoforms in AA and HIs. a The WT and AS isoforms could be detected in all of the healthy individuals (lane 1), $64 \%$ of the AA patients contained $\mathrm{WT}^{+} \mathrm{AS}^{+} \mathrm{CD} 3 \zeta 3^{\prime}-$ UTR (lane 2), $22 \%$ of the AA patients had only the $\mathrm{WT}^{+} \mathrm{AS}^{-} \mathrm{CD} 3 \zeta 3^{\prime}-$ UTR (lanes 4 and 5), and $14 \%$ of the AA patients had only the WTAS ${ }^{+}$CD3 $\zeta 3^{\prime}$-UTR (lanes 6 and 7). Lane 3 is a 100 bp DNA ladder; $\mathbf{b}$ the expression level of the CD3 gene with different $\mathrm{CD} 3 \zeta 3^{\prime}-$ UTR splicing variant isoforms in SAA 
a

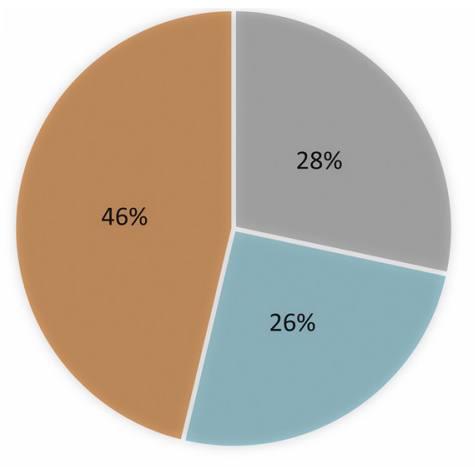

$\approx A G=A A=G G$

C

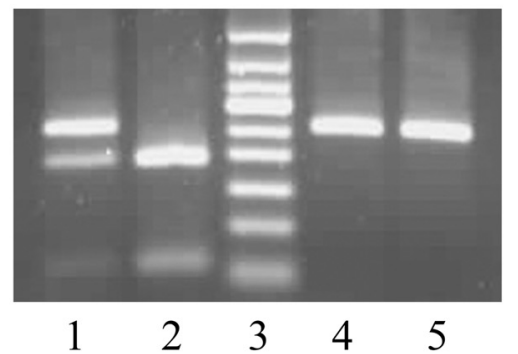

e

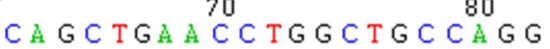

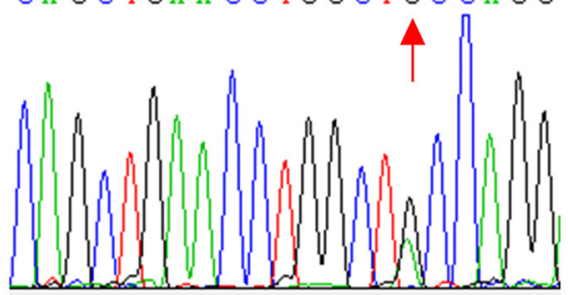

b

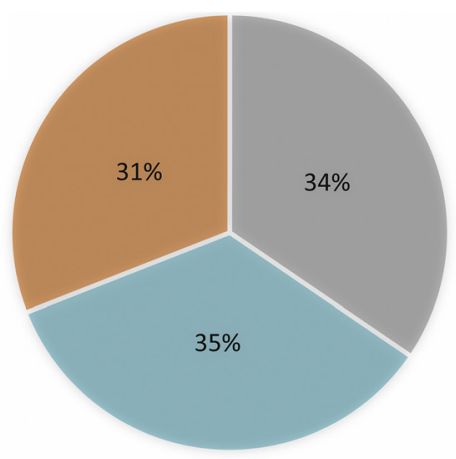

$\because A G=A A=G G$

d

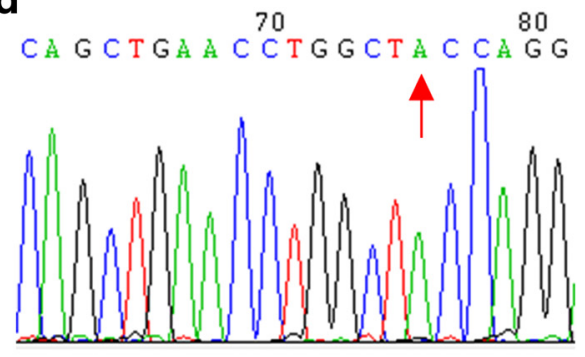

f CA G CTGA A C $\stackrel{70}{\mathrm{C} T G G \text { CT G C CA G }} \stackrel{80}{0}$

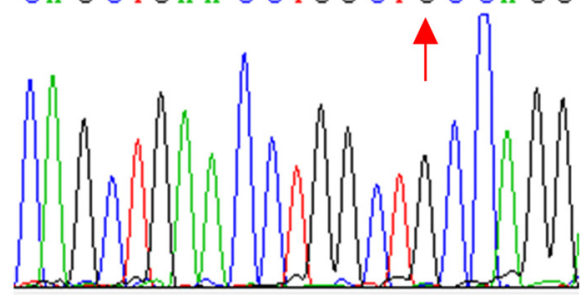

Fig. 4 The genotype characteristic of SNP rs 231775 in CTLA-4 gene in AA and HIs. a Distribution of the genotype of SNP rs231775 in AA patients $(n=67) ; \mathbf{b}$ distribution of the genotype of SNP rs 231775 in HIs $(n=84)$; c agarose gel electrophoresis results for SNP rs 231775 in CTLA-4 gene, lane 1 is the AG genotype, lane 2 is the GG genotype, lane 3 is a 50 bp DNA ladder, lane 4 is the AA genotype, and lane 5 is a PCR product without Tsel digestion; $\mathbf{d}$ sequencing results of AA genotype; e sequencing results of AG genotype; $\mathbf{f}$ sequencing results of GG genotype; the red arrow indicates the single-nucleotide polymorphism sites

activation $[25,26]$. In this study, we analyzed the expression of TCR signaling molecules and related factors that are involved in mediating TCR signaling in AA patients.

$\mathrm{T}$ cell activation requires the delivery of at least two signals. The first signal is antigen-specific and MHCTCR ligation, and the second is a co-stimulatory signal $[13,27,28]$. Co-stimulatory signals occur via the binding of CD28, which is located on T cell, with B7 family members on APCs. Initial activation of T cell after antigen exposure is mediated by the CD28/B7 interaction and leads to the proliferation and differentiation of effector $\mathrm{T}$ cell [29]. Co-stimulation cannot proceed unchecked; otherwise, an overwhelming immune response will ultimately ruin the host. The co-stimulatory system consists of peculiar mechanisms that can dampen $\mathrm{T}$ cell activation signals, resulting in immune homeostasis. CTLA-4, an inhibitory signaling molecule that prevents $\mathrm{T}$ cell activation, becomes expressed on activated $\mathrm{T}$ cell when $\mathrm{T}$ cell activation has reached its peak [30, 31]. CD28 and CTLA-4 control the threshold for $\mathrm{T}$ cell activation by regulating the level of Cbl-b expression [19, 20].

In this study, we analyzed the expression characteristics of the CD3 $\zeta$, CD28, CTLA-4, and Cbl-b genes, and our data indicate significantly decreased CTLA-4 and $\mathrm{Cbl}-\mathrm{b}$ and increased $\mathrm{CD} 3 \zeta$ and $\mathrm{CD} 28$ expression in AA patients. These results suggest that there may be aberrant $\mathrm{T}$ cell activation, which may be related to the first and second signals of the $\mathrm{T}$ cell activation signaling 


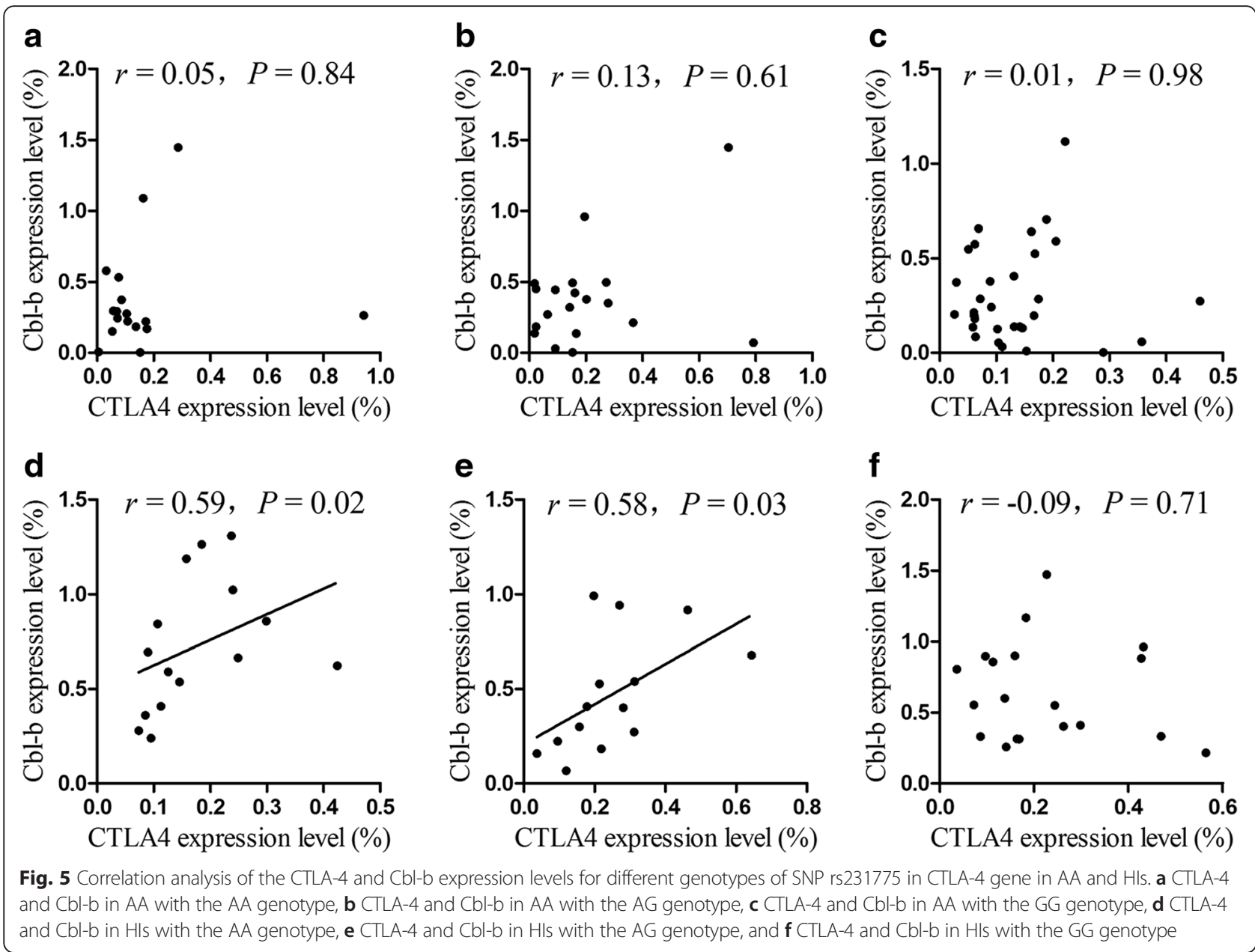

molecules in AA. However, do the other signaling molecules of TCR signaling such as $\mathrm{CD} 3 \gamma, \mathrm{CD} 3 \delta, \mathrm{CD} 3 \varepsilon$, and ZAP-70 [32, 33] also have similar change trend in AA, it is needed further investigation, and it is suggested to characterize the alteration of gene expression profile. Downregulated Cbl-b gene expression in AA suggests that the threshold for $\mathrm{T}$ cell activation is different from that in healthy individuals. There is variation in the CD3 gene expression level in SAA and NSAA patients, which indicates that an aberrant $\mathrm{T}$ cell activation is more obvious in NSAA patients and may help distinguish between SAA and NSAA patients for immunosuppressive treatments in the clinic.

It is known that $\mathrm{CD} 3 \zeta$ is the key regulator of the TCR/ CD3 complex in T cell activation [34, 35]. The increased $\mathrm{CD} 3 \zeta$ expression in AA samples indicated abnormal $\mathrm{T}$ cell activation at least in some subsets of $\mathrm{T}$ cell in the patients, while a differently significant $\mathrm{CD} 3 \zeta$ gene expression pattern was found for SAA and NSAA in this study. However, the underlying mechanism remains unclear because a previous study showed that different distributions of the CD3 $33^{\prime}$-UTR isoforms may affect
$\mathrm{CD} 3 \zeta$ and its related gene expression. Therefore, we compared the $\mathrm{CD} 3 \zeta$ expression characteristics in subgroups containing different combinations of the $\mathrm{CD} 3 \zeta$ 3 '-UTR isoforms.

In general, the WT and AS 3'-UTR play different roles in $\mathrm{CD} 3 \zeta$ transcript stability and generation of the $\mathrm{CD} 3 \zeta$ protein [36]. In this study, we first characterized the distribution of the WT and AS 3'-UTRs in AA patients. Interestingly, we found that only $64 \%$ of the AA samples expressed $\mathrm{WT}^{+} \mathrm{AS}^{+} \mathrm{CD} 3 \zeta 3^{\prime}$-UTR, which was thought to be the normal genotype. We also found two different subgroups, $\mathrm{WT}^{+} \mathrm{AS}^{-} \mathrm{CD} 3 \zeta 3^{\prime}$-UTR $(22 \%)$ and $\mathrm{WT}^{-} \mathrm{AS}^{+} \mathrm{CD} 3 \zeta 3^{\prime}-\mathrm{UTR}(14 \%)$, in the AA patients, which may be related to the change in the $\mathrm{CD} 3 \zeta$ level in the patients. Because we could not find a difference in the $\mathrm{CD} 3 \zeta$ expression level in the total AA samples, we further compared the SAA and NSAA groups. Notably, an increased $\mathrm{CD} 3 \zeta$ expression level was found in the $\mathrm{WT}^{-} \mathrm{AS}^{+} \mathrm{CD} 3 \zeta 3^{\prime}$-UTR SAA group compared with both the $\mathrm{WT}^{+} \mathrm{AS}^{+} \mathrm{CD} 3 \zeta 3^{\prime}$-UTR and $\mathrm{WT}^{+} \mathrm{AS}^{-}$ CD3 $\zeta 33^{\prime}$-UTR SAA groups. Interestingly, there was no significant difference in the $\mathrm{CD} 3 \zeta$ expression level 
between the $\mathrm{WT}^{+} \mathrm{AS}^{+}, \mathrm{WT}^{-} \mathrm{AS}^{+}$, and $\mathrm{WT}^{+} \mathrm{AS}^{-}$subgroups for the NSAA patients. Therefore, there may be a difference in the regulation of the $\mathrm{CD} 3 \zeta$ expression level and $\mathrm{T}$ cell activation between SAA and NSAA. At a minimum, it is thought that the CD3 $33^{\prime}$-UTR isoforms may influence the $\mathrm{CD} 3 \zeta$ expression level in T cells from SAA, which may be one reason for the abnormal $\mathrm{T}$ cell activation.

It has been reported that aberrant $\mathrm{CD} 3 \zeta$ expression may be associated with the decreased stability and trans-

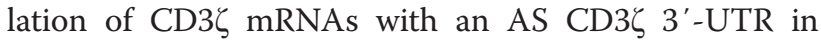
SLE $[22,36]$. In this study, the $\mathrm{CD} 3 \zeta$ gene expression level in some SAA patients was thought to be affected by different splicing variants of the CD3 $\zeta 3$ '-UTR. As our results demonstrated, there was an increased $\mathrm{CD} 3 \zeta$ expression level in SAA patients with the $\mathrm{WT}^{-} \mathrm{AS}^{+} \mathrm{CD} 3 \zeta$ 3 '-UTR genotype, and whether this is feedback regulation remains an open question. The $\mathrm{T}$ cell activation function in SAA patients will be examined in the future to evaluate the influence of the CD3 $33^{\prime}$-UTR isoforms. To characterize the positive and negative regulatory factors of the TCR signal pathway, it is necessary to analyze the characteristics of the negative factors e.g., CTLA-4 and Cbl-b. It has been reported that SNP rs231775 in CTLA-4 gene is associated with an increased frequency of autoimmune diseases such as Graves' disease, autoimmune hypothyroidism, type I diabetes, and multiple sclerosis [37-39]. ]s To determine whether this SNP also plays a role in AA, we analyzed its distribution in AA samples. To our knowledge, this is the first study to analyze this SNP in Chinese AA patients. Interestingly, we found that the homozygous GG mutant was significantly higher in AA patients, indicating that this CTLA4 variant may have an association with susceptibility to developing AA. However, this result is in contrast with a report by Svahn J et al. who demonstrated that there were no significant differences in the genotype or allele frequency of SNP rs231775 in CTLA-4 gene between AA patients and healthy individuals in the Caucasian population [40]. However, the CTLA-4 mRNA expression level had no significant association with the genotype of SNP rs231775 in CTLA-4 gene in this study because SNP rs231775 is associated with the protein level $[17,18]$. Further study is needed to analyze the CTLA-4 protein level in T cell from AA patients to confirm this result.

CTLA-4 regulates TCR signals via Cbl-b, and it plays an important role in regulating it at the transcriptional level [20]. However, little is known about the mRNA expression pattern of CTLA-4 and Cbl-b in AA patients. In this study, we found a significant positive correlation between CTLA-4 and Cbl-b in healthy individuals with the AA and AG genotypes of SNP rs231775 in CTLA-4 gene but not in those with the GG genotype of SNP rs231775 in CTLA-4 gene. However, there was no significant correlation between CTLA-4 and Cbl-b in any of the patients. These results indicate that CTLA-4 loses its proper regulatory role of Cbl-b expression at the transcriptional level in AA patients.

\section{Conclusion}

In conclusion, this is the first study to analyze the expression characteristics of the CD28, CTLA-4, and Cbl-b genes, the distribution of the CD3 3 3'-UTR splice variant in AA patients, and the SNP rs231775 in CTLA4 gene in Chinese AA patients. We found that aberrant $\mathrm{T}$ cell activation may be associated with either the first or second $\mathrm{T}$ cell activation signaling molecules in AA. Different $\mathrm{CD} 3 \zeta$ expression patterns in SAA and NSAA patients suggest different abnormal alternative $\mathrm{CD} 3 \zeta$ pathway patterns in SAA and NSAA patients. The mutant type homozygous GG and G allele for SNP rs231775 in CTLA-4 gene might be associated with AA risk for the Chinese population.

\section{Methods \\ Samples}

The AA group consisted of 67 patients with newly diagnosed AA (36 cases with SAA and 31 with NSAA, including 37 males and 30 females; median age 34 years, range 9-78 years). The information and clinical data of the patients are described in Table 1. Forty-eight healthy individuals (21 males and 27 females; median age 35.5 years, range $20-80$ years) were used for detecting CD3, , CD28, CTLA-4, and Cbl-b genes expression levels and CD3 3 '-UTR isoform, and 84 healthy individuals (40 males and 44 females; median age 33 years, range 688 years) were used for detecting for SNP rs231775 in CTLA-4 gene. AA diagnoses were established by bone marrow biopsy and peripheral blood counts. All of the

\begin{tabular}{ll}
$\begin{array}{l}\text { Table } \mathbf{1} \text { The demographic and clinical characteristics of AA } \\
\text { patients }\end{array}$ \\
\hline Patients characteristics $(n=67)$ & No. $(\%)$ \\
\hline Age (years) & Redian 34.0 \\
Gender & \\
Male & $37(55.2)$ \\
Female & $30(44.8)$ \\
Severity of AA & \\
AA & $31(46.3)$ \\
SAA & $36(53.7)$ \\
Clinical data & \\
Hb $(g / L)$ & Median 65.0 \\
ANC $\left(10^{9} / \mathrm{L}\right)$ & Median 0.38 \\
PLT $\left(10^{9} / \mathrm{L}\right)$ & Median 11.5 \\
\hline Hb hemoglobin, ANC absolute neutrophil count, $P L T$ platelet &
\end{tabular}


procedures were performed according to the guidelines of the Medical Ethics committee of the health bureau of the Guangdong Province of China. Peripheral blood mononuclear cell (PBMC) isolation, RNA and DNA extraction, and cDNA synthesis were performed according to the manufacturer's instructions.

\section{RT-PCR for CD3 3 3'-UTR isoform}

The primer specificity for CD3ל 3'-UTR amplification was as follows: forward 5 '-CAGCCAGGGGATTTCACCACTCAAAG-3' reverse 5'-CCCTAGTACATTGACG GGTTTTTCCTG-3' [41]. The amplification was carried out after initial denaturation at $94{ }^{\circ} \mathrm{C}$ for $4 \mathrm{~min}, 30$ cycles at $94{ }^{\circ} \mathrm{C}, 45 \mathrm{~s} ; 67^{\circ} \mathrm{C}, 1 \mathrm{~min} ; 72{ }^{\circ} \mathrm{C}$ for $2 \mathrm{~min}$; and a final extension at $72{ }^{\circ} \mathrm{C}$ for $7 \mathrm{~min}$. After completion of the PCR, $20 \mu \mathrm{l}$ of the PCR products were electrophoresed on a $1.5 \%$ agarose gel.

\section{Real-time relative quantitative PCR for the $\mathrm{CD} 3 \zeta$, $\mathrm{CD} 28$, CTLA-4, and Cbl-b genes}

Real-time PCR using the SYBR Green I method [42, 43] was used to examine the CD3, CD28, CTLA-4, and Cbl-b genes with cDNA obtained from the PBMCs of AA patients and healthy individuals. The $\mathrm{CD} 3 \zeta$ and $\beta_{2} \mathrm{M}$ primer sequences and PCR conditions were previously described [26]. The other primer sequences were as follows: CD28: 5'-GAAACACCTTTGTCCAA GTC-3' and 5'-GGGGAGTCATGTTCATGTAG-3', CTLA-4: 5' GTCAGCCTGCCGAAGC ACT-3' and 5'-GTCAGCC TGCCGAAGCACT-3', and Cbl-b: 5'-CCCTGGAATTG ACCATTGGG-3' and 5'-ACTTGCCCAACTCAGTGA GAA-3'. The real-time PCR reactions were performed in a total volume of $25 \mu \mathrm{l}$ containing approximately $1 \mu \mathrm{l}$ cDNA, $0.5 \mu \mathrm{M}$ of each primer pair, and $11.25 \mu \mathrm{l} 2.5 \times$ RealMasterMix (Tiangen, Beijing). After an initial denaturation at $95{ }^{\circ} \mathrm{C}$ for $15 \mathrm{~min}, 40$ cycles of the following procedure were performed using an MJ Research DNA Engine Opticon 2 PCR cycler (BIO-RAD, Hercules, CA, USA): $15 \mathrm{~s}$ at $95{ }^{\circ} \mathrm{C}$ and $30 \mathrm{~s}$ at $60{ }^{\circ} \mathrm{C}$ followed by $1 \mathrm{~s}$ at $80{ }^{\circ} \mathrm{C}$ for plate reading. The $2\left({ }^{-\Delta \mathrm{CT}}\right)$ method was used to analyze the genes of interest relative to an internal control gene.

\section{Polymerase chain reaction and restriction fragment length polymorphism (RFLP)}

The SNP rs231775 in CTLA-4 gene exon 1 were amplified using the following primers: 5'-CACATGTGTAATACATATCTGGG-3' and $5^{\prime}$ 'TTGCAGAAGACAGGG ATG AAGA-3'. The polymerase chain reaction (PCR) mixture contained $100 \mathrm{ng}$ of genomic DNA, $0.1 \mathrm{mM}$ each of deoxynucleotide triphosphates, $12.5 \mathrm{pmol}$ each of the primers, and $1 \mathrm{U}$ Taq polymerase (Applied Biosystems, Foster City, CA, USA) in a $25 \mu \mathrm{l}$ final volume. The samples were heated at $95{ }^{\circ} \mathrm{C}$ for $2 \mathrm{~min}$ followed by
35 cycles of $94{ }^{\circ} \mathrm{C}$ for $60 \mathrm{~s}, 60{ }^{\circ} \mathrm{C}$ for $60 \mathrm{~s}$, and $72{ }^{\circ} \mathrm{C}$ for $60 \mathrm{~s}$ with a final extension at $72{ }^{\circ} \mathrm{C}$ for $5 \mathrm{~min}$. The PCR products $(50 \mu \mathrm{l})$ were digested overnight with the restriction enzyme TseI (NEB, UK) according to the manufacturer's protocol, and they were analyzed by $2.5 \%$ agarose gel electrophoresis. The digestion of PCR products in the presence of the restriction sites is indicative of the presence of the $G$ allele. The finding of a single band of $250 \mathrm{bp}$ is indicative of the AA genotype, whereas the GG genotype is indicated by the finding of two bands at 189 and $61 \mathrm{bp}$. On the other hand, the AG genotype is characterized by the appearance of three bands: one at $250 \mathrm{bp}$ and the others at 189 and $61 \mathrm{bp}$. The different genotypes were successfully confirmed by DNA sequencing.

\section{Statistical analysis}

The Mann-Whitney test was performed to compare each gene expression level between different groups. Spearman correlation analyses were used to estimate correlations between different gene expression levels. Fisher's exact test was used to compare genotypes or allelic frequencies between different groups. A $P<0.05$ was considered to be statistically significant.

\section{Competing interests}

The authors declare that they have no competing interests.

\section{Authors' contributions}

$\mathrm{BL}$ and $\mathrm{YQL}$ contributed to concept development and study design. $\mathrm{BL}, \mathrm{LXG}$ YKX, MJW, and LLZ performed the laboratory studies. YPZ, XL, SHC, and LJY were responsible for collection of clinical data. BL and YQL coordinated the study and helped draft the manuscript. All authors read and approved the final manuscript.

\section{Acknowledgements}

This study was sponsored by grants from the National Natural Science Foundation of China (\#81370605 and \#81460026), a China Post-doctoral Science Foundation funded project (\#20070410840), the Natural Science Foundation of Guangdong Province (\#S2012010008794 and \#S2013020012863), the Technology Program of Guangdong Province (\#2014A020212209), the Foundation for High-level Talents in Higher Education of Guangdong, China (\#[2013]246-54), a Science and Information Technology of Guangzhou funded basic research for application project (\#2011 J4100028), and Fundamental Research Funds for the Central Universities (\#21612425).

\section{Author details}

${ }^{1}$ Institute of Hematology, Medical College, Jinan University, Guangzhou, China. 'Department of Hematology, Guangzhou First Municipal People's Hospital Affiliated to Guangzhou Medical College, Guangzhou, China. ${ }^{3}$ Key Laboratory for Regenerative Medicine of Ministry of Education, Jinan University, Guangzhou, China. ${ }^{4}$ Department of Hematology, Affiliated Hospital of Youjiang Medical University for Nationalities, Baise, China. ${ }^{5}$ Department of Hematology, First Affiliated Hospital, Jinan University, Guangzhou, China.

Received: 26 January 2016 Accepted: 18 March 2016 Published online: 31 March 2016

\footnotetext{
References

1. Young NS, Scheinberg P, Calado RT. Aplastic anemia. Curr Opi Hematol. 2008;15(3):162-8.

2. Young NS, Ogawa S. Somatic mutations and clonal hematopoiesis in aplastic anemia. N Engl J Med. 2015;373(17):1675-6.
} 
3. Killick SB, Bown N, Cavenagh J, Dokal I, Foukaneli T, Hill A, et al. Guidelines for the diagnosis and management of adult aplastic anaemia. $\mathrm{Br} \mathrm{J}$ Haematol. 2016;172(2):187-207.

4. Vo PT, Pantin J, Ramos C, Cook L, Cho E, Kurlander R, et al. Conditioning with rabbit versus horse ATG dramatically alters clinical outcomes in identical twins with severe aplastic anemia transplanted with the same allogeneic donor. J Hematol Oncol. 2015;8:78.

5. Hosokawa K, Muranski P, Feng X, Townsley DM, Liu B, Knickelbein J, et al. Memory stem $T$ cells in autoimmune disease: high frequency of circulating CD8+ memory stem cells in acquired aplastic anemia. J Immunol. 2016; 196(4):1568-78.

6. Li B, Liu S, Niu Y, Fang S, Wu X, Yu Z, et al. Altered expression of the TCR signaling related genes CD3 and FceRly in patients with aplastic anemia. J Hematol Oncol. 2012;5:6.

7. Clemente-Casares $X$, Blanco J, Ambalavanan P, Yamanouchi J, Singha S, Fandos $C$, et al. Expanding antigen-specific regulatory networks to treat autoimmunity. Nature. 2016;17. doi: 10.1038/nature16962.

8. Ji X, Zhang L, Peng J, Hou M. T cell immune abnormalities in immune thrombocytopenia. J Hematol Oncol. 2014;7:72.

9. Wooldridge L, Individual MHC. I-restricted T-cell receptors are characterized by a unique peptide recognition signature. Front Immunol. 2013:4:199.

10. Li Y, Chen S, Yang L, Chen S, Lin C, Wang L, et al. Change in expression pattern of TCR-CD3 complex in patients with multiple myeloma. Hematology. 2011;16(3):143-50.

11. Ville S, Poirier N, Blancho G, Vanhove B. Co-stimulatory blockade of the CD28/CD80-86/CTLA-4 balance in transplantation: impact on memory $T$ cells? Front Immunol. 2015;6:411.

12. Goel G, Sun W. Advances in the management of gastrointestinal cancers - an upcoming role of immune checkpoint blockade. J Hematol Oncol. 2015:8:86.

13. Chen L, Flies DB. Molecular mechanisms of T cells co-stimulation and co-inhibition. Nat Rev Immunol. 2013;13(4):227-42.

14. Nurieva RI, Liu X, Dong C. Yin-Yang of costimulation: crucial controls of immune tolerance and function. Immunol Rev. 2009;229(1):88-100.

15. Aronin A, Amsili S, Prigozhina TB, Tzdaka K, Shen R, Grinmann L, et al. Highly efficient, in-vivo Fas-mediated apoptosis of B-cell lymphoma by hexameric CTLA4-FasL. J Hematol Oncol. 2014;7:64.

16. Buchbinder E, Hodi FS. Cytotoxic T lymphocyte antigen-4 and immune checkpoint blockade. J Clin Invest. 2015;125(9):3377-83.

17. Barton A, Jury F, Eyre S, Bowes J, Hinks A, Ward D, et al. Haplotype analysis in simplex families and novel analytic approaches in case-control cohort reveal no evidence of association of the CTLA-4 gene with rheumatoid arthritis. Arthritis Rheum. 2004;50(3):748-52.

18. Muñoz-Valle JF, Valle Y, Padilla-Gutiérrez JR, Parra-Rojas I, Rangel-Villalobos $H$, Vázquez del Mercado M. The $+49 A>G$ CTLA-4 polymorphism is associated with rheumatoid arthritis in Mexican population. Clin Chim Acta. 2010:411(9-10):725-8.

19. Krawczyk CM, Jones RG, Atfield A, Bachmaier K, Arya S, Odermatt B, et al. Differential control of CD28-regulated in vivo immunity by the E3 ligase Cbl-b. J Immunol. 2005;174(3):1472-8

20. Li D, Gál I, Vermes C, Alegre ML, Chong AS, Chen L, et al. Cutting edge: Cbl-b: one of the key molecules tuning CD28 and CTLA-4-mediated T cell costimulation. J Immunol. 2004:173(12):7135-9.

21. Clevers H, Alarcon B, Wileman T, Terhorst C. The T cell receptor/CD3 complex: a dynamic protein ensemble. Annu Rev Immunol. 1988;6:629-62.

22. Nambiar MP, Enyedy EJ, Warke VG, Krishnan S, Dennis G, Kammer GM, et al. Polymorphisms/mutations of TCR-zeta-chain promoter and 3'untranslated region and selective expression of TCR zeta-chain with an alternatively spliced 3'untranslated region in patients with systemic lupus erythematosus. J Autoimmun. 2001;16(2):133-42.

23. Hosokawa K, Muranski P, Feng X, Keyvanfar K, Townsley DM, Dumitriu B, et al. Identification of novel microRNA signatures linked to acquired aplastic anemia. Haematologica. 2015;100(12):1534-45.

24. Yan L, Fu R, Liu H, Wang H, Liu C, Wang T, et al. Abnormal quantity and function of regulatory $T$ cells in peripheral blood of patients with severeaplastic anemia. Cell Immunol. 2015;296(2):95-105.

25. Liu X, Berry CT, Ruthel G, Madara JJ, MacGillivray K, Gray CM, et al. T cell receptor-induced NF-KB signaling and transcriptional activation are regulated by STIM1- and Orai1-mediated calcium entry. J Biol Chem. 2016. (In press).
26. Schnorfeil FM, Lichtenegger FS, Emmerig K, Schlueter M, Neitz JS, Draenert R, et al. T cells are functionally not impaired in AML: increased PD-1 expression is only seen at time of relapse and correlates with a shift towards the memory $T$ cell compartment. J Hematol Oncol. 2015;8:93.

27. Xie A, Zheng X, Khattar M, Schroder P, Stepkowski S, Xia J, et al. TCR stimulation without co-stimulatory signals induces expression of "tolerogenic" genes in memory CD4 T cells but does not compromise cell proliferation. Mol Immunol. 2015;63(2):406-11.

28. Xu L, Zhang Y, Luo G, Li Y. The roles of stem cell memory $T$ cells in hematological malignancies. J Hematol Oncol. 2015;8(1):113.

29. Gardner D, Jeffery LE, Sansom DM. Understanding the CD28/CTLA-4 (CD152) pathway and its implications for costimulatory blockade. Am J Transplant. 2014;14(9):1985-91.

30. Tsai KK, Daud Al. Nivolumab plus ipilimumab in the treatment of advanced melanoma. J Hematol Oncol. 2015:8(1):123.

31. Callahan MK, Postow MA, Wolchok JD. CTLA-4 and PD-1 pathway blockade: combinations in the clinic. Front Oncol. 2015;4:385.

32. Köhnke T, Krupka C, Tischer J, Knösel T, Subklewe M. Increase of PD-L1 expressing B-precursor ALL cells in a patient resistant to the CD19/CD3bispecificT cell engager antibody blinatumomab. J Hematol Oncol. 2015;8(1):111.

33. Liao Z, Zhou L, Wang C, He Z, Wang X, Luo X, et al. Characteristics of TCR ZAP-70, and FcERly gene expression in patients with T- and NKT-cell lymphoma. DNA Cell Biol. 2015;34(3):201-7.

34. Chen S, Zha X, Shi L, Zhou L, Yang L, Li B, et al. Upregulated TCR improves cytokine secretion in T cell from patients with AML. J Hematol Oncol. 2015:8:72

35. Niu Y, Yu W, Fang S, Liu S, Yang Z, Liu W, et al. Lead poisoning influences TCR-related gene expression patterns in peripheral blood T-lymphocytes of exposed workers. J Immunotoxicol. 2015;12(1):92-7.

36. Nambiar MP, Enyedy EJ, Warke VG, Krishnan S, Dennis G, Wong HK, et al. T cell signaling abnormalities in systemic lupus erythematosus are associated with increased mutations/polymorphisms and splice variants of T cell receptor zeta chain messenger RNA. Arthritis Rheum. 2001:44(6):1336-50.

37. Du P, Ma X, Wang C. Associations of CTLA4 gene polymorphisms with Graves' ophthalmopathy: a meta-analysis. Int J Genomics. 2014;2014:537969.

38. Wang J, Liu L, Ma J, Sun F, Zhao Z, Gu M. Common variants on cytotoxic T lymphocyte antigen-4 polymorphisms contributes to type 1 diabetes susceptibility: evidence based on 58 studies. PLoS One. 2014;9(1):e85982.

39. Banelli B, Morabito A, Laurent S, Piccioli P, Dozin B, et al. A novel multiplex pyrosequencing assay for genotyping functionally relevant CTLA-4 polymorphisms: potential applications in autoimmunity and cancer. Hum Immunol. 2014;75(8):730-9.

40. Svahn J, Capasso M, Lanciotti M, Marrone A, Haupt R, Bacigalupo A, et al. The polymorphisms $-318 \mathrm{C}>\mathrm{T}$ in the promoter and $49 \mathrm{~A}>\mathrm{G}$ in exon 1 of CTLA4 and the risk of aplastic anemia in a Caucasian population. Bone Marrow Transplant. 2005:35 Suppl 1:S89-92.

41. Weissman AM, Hou D, Orloff DG, Modi WS, Seuanez H, O'Brien SJ, et al. Molecular cloning and chromosomal localization of human T-cell receptor chain: Distinction from molecular CD3 complex. Proc Natl Acad Sci U S A. 1988:85:9709-13.

42. Zeng C, Yu X, Lai J, Yang L, Chen S, Li Y. Overexpression of the long noncoding RNA PVT1 is correlated with leukemic cell proliferation in acute promyelocytic leukemia. J Hematol Oncol. 2015;8(1):126.

43. Skvarova Kramarzova K, Fiser K, Mejstrikova E, Rejlova K, Zaliova M, et al. Homeobox gene expression in acute myeloid leukemia is linked to typical underlying molecular aberrations. J Hematol Oncol. 2014;7:94.

\section{Submit your next manuscript to BioMed Central and we will help you at every step:}

- We accept pre-submission inquiries

- Our selector tool helps you to find the most relevant journal

- We provide round the clock customer support

- Convenient online submission

- Thorough peer review

- Inclusion in PubMed and all major indexing services

- Maximum visibility for your research

Submit your manuscript at www.biomedcentral.com/submit 